fruitful field of research. Its present state is described in Ref. 5 which we recommend for further consultation.

\section{REFERENCES}

1. Andres K., Graebner J.E. and Ott H.R., Phys. Rev. Lett. 35 (1975) 1779.

2. Steglich F., Aarts J., Bredl C.D., Lieke W., Meschede D., FranzW. and Schäfer H., Phys. Rev. Lett. 43 (1979) 1892.

3. Stewart G.R., Rev. Mod. Phys. 56 (1984) 755.

4. Lüthi B., Chapter 4 in Dynamical Properties of Solids, Vol. 3, Eds. G.K. Horton and A.A. Maradudin, (North-Holland, Amsterdam) 1980

5. Proceedings of the "International Conference on Valence Fluctuations", Eds. E. Müller-Hartmann, B. Rhoden and D. Wohlleben, J. Mag. Mag. Mat. 47 and 48 (1985).

\section{JPS Collaboration}

Under the terms of an agreement concluded with the Physical Society of Japan (JPS), members of JPS may join the EPS as Category 4d) members (members of a Collaborating Society) on payment of a membership fee (for 1986) of Sw.Frs. 55. - (US\$26.-). In addition, members of JPS may submit papers to EPS meetings on the same conditions as EPS members, and will be entitled to pay the same registration fees for EPS meetings as members of EPS member societies.

In return, Individual Ordinary Members of EPS may submit papers to JPS meetings under the same conditions as JPS members, pay the same registration fees and may subscribe to the Journal of the Physical Society of Japan at the same rates as JPS members. Subscriptions for 1986 (vol. 55) should be addressed by 31 December 1985 to:

The Physical Society of Japan

Room 211, Kikai-Shinko Blg.

3-5-8 Shiba-Koen, Minato-ku

Tokyo 105, Japan

EPS Divisions, Sections and Group

Astronomy and Astrophysics Division Solar Physics Section

Atomic and Molecular Physics Division Atomic Spectroscopy Section Chemical Physics

Electronic and Atomic Collisions Molecular Physics

Computational Physics Group

Condensed Matter Division

Liquids Section

Low Temperature Physics Section

Macromolecular Physics

Magnetism

Metal Physics

Semiconductors and Insulators

Surfaces and Interfaces

High Energy \& Particle Physics Division

Nuclear Physics Division

Optics Division

Optics Division
Plasma Physics Division

Quantum Electronics Division

\title{
EPS Lecturer 1985/1986
}

The EPS Lecturer for $1985 / 86$ is Professor H. Haken of the University of Stuttgart. $\mathrm{He}$ is well known especially for his original work on "Synergetics"* but he has also made basic contributions to the quantum field theory of the solid state, to statistical physics and to quantum optics. Professor Haken's lecture tour will consist of two parts: from 20 October until 7 November 1985 he will visit three Scandinavian countries and England, and then next year he will spend two-three weeks in January/ February travelling through France, Portugal, Spain, Italy and Israel.

He will be presenting three lectures:

1. Synergetics, an overview

2. Theory of non-equilibrium phase transitions, slaving principle and order parameters

3. Pattern formation in systems far from thermal equilibrium.

\section{Programme of the First Part}

\begin{tabular}{|c|c|c|c|c|c|}
\hline & Date, 1985 & Location & Time & Lecture & Contact \\
\hline \multirow[t]{10}{*}{ Oct. } & 21 & Helsinki & 14.30 & 1 & S. Stenholm \\
\hline & 22 & Helsinki & $10: 30$ & 3 & S. Stenholm \\
\hline & 23 & Turku & $14: 15$ & 1 & M. Punkkinen \\
\hline & 24 & Turku & $10: 15$ & 2 & M. Punkkinen \\
\hline & 25 & Stockholm & $10: 00$ & 1 & B. Nagel \\
\hline & 25 & Stockholm & $14: 00$ & 3 & B. Nagel \\
\hline & 28 & Göteborg & $15: 15$ & 3 & B. Lundqvist \\
\hline & 29 & Göteborg & $15: 15$ & 1 & B. Lundqvist \\
\hline & 30 & Lund & $15: 30$ & 1 & B.E. Svensson \\
\hline & 31 & Lund & $10: 30$ & 3 & B.E. Svensson \\
\hline \multirow[t]{5}{*}{ Nov. } & 1 & Lyngby & $15: 00$ & 1 & P. Christianssen \\
\hline & 4 & Bristol & $14: 15$ & 3 & R.G. Chambers \\
\hline & 4 & Bristol & $17: 00$ & 1 & R.G. Chambers \\
\hline & 6 & Birmingham & $17: 00$ & 1 & W.F. Vinen \\
\hline & 6 or 7 & Birmingham & $14: 15$ & 2 & W.F. Vinen \\
\hline
\end{tabular}

The programme of the second part will be published in the November/December issue of Europhysics News.

* see for example Europhysics News 7 (1976) 7/8, 9.

Subscription fee to Europe is as follows:

Surface mail: $\quad$ Yen 13400

Airmail: $\quad$ Yen 38400

Microfilm (airmail): Yen 13400

In his concluding message to EPS, the outgoing President of JPS, Prof. Hiroshi Kamimura (now succeeded by Professor Yoshihiko Ichikawa) referred to the JPS "looking forward to a mutually beneficial exchange".

Europhysics News is the official journal of the European Physical Society which comprises 29 National Societies, Academies and Group, over 4000 Individual Members and 71 Associate Members. Governing bodies of EPS are the General Meeting, Council and an elected Executive Committee responsible for detailed policy. EPS promotes the collaboration of physicists throughout Europe, organising and harmonising conferences and publications, improving physics education, encouraging physics applications, awarding scholarships to sponsored schools in Erice. EPS publishes in addition to EN, Europhysics Conference Abstracts, E. Ed. News and, in collaboration with The Institute of Physics (UK). the European Journal of Physics. Individual Members receive EN free of charge (price to institutions: Sw.Fr. $90 .-1 a)$, rebates on the price of many publications and on conference fees. Annual EPS membership fee for 1986: Individual Members belonging to an EPS member society is: Sw.Fr. 44.; independent members: Sw.Fr. 132-; members of a Collaborating Society, e.g. the American Physical Society: Sw.Fr. 55.- (\$ 26).

\section{New Associate Member}

The latest organisation to become an Associate Member of EPS is:

\section{S.A.B.C.A. - Société Anonyme Belge de Construction Aéronautique 1470 Chaussée de Haecht B - 1130 Brussels}

\section{Editor: E.N. Shaw \\ Meetings Compilation: W.S. Newman \\ Editorial Board: \\ K. Appert, A. Baratoff, B. Jacrot, \\ G.R. Macleod, M. Mayor, J. Muller}

Editorial and Advertising Office at the EPS Secretariat

Address: EUROPEAN PHYSICAL SOCIETY P.O. Box 69 , $\mathrm{CH}-1213$ Petit-Lancy 2

Switzerland

Telephone: Geneva (22) 931130

Telex : $\mathbf{4 2 3} \mathbf{4 5 5}$ dema ch

Cables: europhys genève

Printed by: Pfirter frères sa $\mathrm{CH}-1213$ Petit-Lancy/Switzerland 